\title{
Indigenous “Folk" Geographical Ideas and Knowledge
}

\author{
Hong-Key Yoon \\ University of Auckland, Auckland, New Zealand \\ Email: hk.yoon@auckland.ac.nz
}

How to cite this paper: Yoon, H.-K. (2017). Indigenous "Folk" Geographical Ideas and Knowledge. Advances in Anthropology, 7, 340-355.

https://doi.org/10.4236/aa.2017.74020

Received: October 10, 2017

Accepted: November 14, 2017

Published: November 17, 2017

Copyright (C) 2017 by author and Scientific Research Publishing Inc. This work is licensed under the Creative Commons Attribution International License (CC BY 4.0).

http://creativecommons.org/licenses/by/4.0/

\begin{abstract}
This paper advocates the need for studying indigenous folk geographical ideas and knowledge in addition to academic geographic ideas and knowledge to encompass all types of geographic tradition in a cross-cultural context. To date, historians of geographic ideas and knowledge in the West have mainly paid attention to Western academic geographic knowledge. Folk and academic geographic ideas and knowledge interact with and influence each other. Academic geography can benefit much from the study of various "folk" traditions. The existence of, and interactions between, the two geographic traditions among different cultures are compelling reasons for the cross-cultural study of folk geographic ideas and knowledge. This paper uses examples from Korea and the Maori people in New Zealand to argue the advantage of studying folk geographic knowledge in a cross-cultural context.
\end{abstract}

\section{Keywords}

Indigenous Folk Geographical Ideas and Knowledge, Geographic Ideas and Knowledge, West, New Zealand Maori, Korea, Cross-Cultural Study

\section{Introduction}

To date, scholars of geographic ideas and knowledge have tended to emphasise those idea held by professional (academic) geographers belonging mainly to academic institutions, government agencies and private businesses. Much less attention has been given to those held by commoners (folk) with no professional training in geography, for example, supposedly "less educated" peasants or people who live in urban ghettos. The term "geographic ideas and knowledge" in this paper refers to any ideas, theories or concepts that help explain geographic phenomena and result in the production of geographical knowledge. It is used in a broad sense to cover any professional geographers' thought or folk (a group of 
people with no formal training in geography) geographic ideas or understandings of place, landscape and people (culture)-environment (nature) relationships.

The term "folk" in folklore studies traditionally referred to poorly educated (sometimes illiterate) peasants in rural areas (Dundes, 1965: p. 2). However, contemporary scholars have established that folklore (folktales, legends, and proverbs) is produced by not just by the people who are classified as folk using the traditional definition, but also by those who are highly literate and part of the rich urban population as well. Thus the traditional definition of the term "folk" is not only prejudiced against the poor and non-literate population by implying that they are somewhat "backward" and inferior, but is too narrow and therefore inadequate for use in anthropological studies. Contemporary American anthropologists accept a much broader definition of folk and prominent folklore scholar Alan Dundes defines it as "any group of people whatsoever who share at least one common factor-it could be a common occupation, language, or religion-but what is important is that a group formed for whatever reason will have some traditions which it calls its own." (Dundes, 1965: p. 2). Dundes has expanded the definition of folk to include any group of people sharing at least one common characteristic or tradition. The modern anthropological definition of folk considers a highly educated elite group of scholars or government officers as a folk group as long as they have a common thing to share. In geography, while defining the nature of ethnogeography J.M. Blaut presented a comparable comment to Alan Dundes's definition of “folk". Blaut (1979: p. 2) argued that the subject matter of ethnogeography is all geographical beliefs held by a human group at a time, and suggested that "the group may be of a culture, a subculture, a class, a profession, an age-group or whatever”. It seems that modern scholarship has attempted to remove the dichotomy between scholarly or official traditions and folk or unofficial and common traditions. However, for a scholar to compare and contrast official or scholarly traditions against the unofficial or indigenous knowledge of folk traditions, this broad definition is too broad and not useful. I am interested in comparing and contrasting professional geographers' geographical knowledge against common people's (non-professional geographers) geographical knowledge. Therefore, I wish to adopt a definition of "folk" closer to the traditional European usage which refers to a group of peasants with little or no formal education, or rural dwelling people. It is a well known fact that the $19^{\text {th }}$ century anthropologists in Europe often applied the term "folk" to poorly educated peasants or rural dwellers (Dundes, 1972: p. 2). Although Dundes' broad definition of folk is theoretically valid and more enlightened than the traditional definition, it is too broad to adopt in this paper. Moving forward, the term, "folk" in this paper will refer to any group of people who are not professionally trained in geography and do not identify themselves as geographers.

This paper aims to advocate the need for studying various kinds of folk geographic knowledge in a cross-cultural context. This paper consists of three parts: 1) a comparison of "folk" and "academic" (professional) geographic knowledge; 
2) the place of folk knowledge in the study of geographic traditions; and 3) the need for and examples of cross-cultural studies of geographic knowledge.

\section{1. "Elite" Traditions and "Folk" Traditions in Geographic Ideas and Knowledge}

The classification of types of geographic ideas and knowledge into different categories is determined by a variety of factors. These include: 1) where (or which national culture) they are from (e.g., French geographic ideas and knowledge), 2) what time they are of: geographic ideas and knowledge on a temporal scale (e.g., Ancient Greek or Roman geographic ideas and knowledge), 3) who the holders of the thought are: whether they are from professional geographers (academic geographic ideas and knowledge) or from non-professional geographers or a folk tradition (indigenous "folk" geographical ideas and knowledge).

Any geographic ideas and knowledge of a nation (ethnic entity or state) at any time may consist of two categories: such views held by professional geographers (academics) and those held by non-professional geographers (folk). Robert Redfield's (1958: p. 70) view of two traditions of a culture-the great (elite) tradition and the little (folk) tradition-can be useful in understanding different dimensions of geographic ideas and knowledge. Adopting his categorisation, one can argue that the geographic ideas held by professional geographers who are trained and provide professional services in the field of geography as academics, researchers or consultants, may represent the great (elite) tradition of "the reflective few", whereas the geographic ideas and knowledge of non-professional geographers may represent the little (folk) tradition of "the largely unreflective many" (Redfield, 1958: p. 70). Indeed, a century ago only a few well known scholars, such as F. Ratzel, E. Semple and E. Huntington, promoted the basic tenet of environmental determinism that attributes environmental conditions as the prime formative factor of human behavioural patterns or cultural characteristics. Their works were influential upon other fellow professional geographers of the elite tradition as well as those in the folk tradition who were not trained as professional geographers. However, at the same time, it can be argued that many members of urban ghettos or rural peasants belonging to various tribal communities recited certain proverbs or told certain stories (e.g., legends) expressing their thoughts on their lives and their surrounding environment. Such folk ideas and views may not be as influential as, say, a scholarly writing, although many people believed such views and ideas, which as a different kind of cultural influence is one that carries its own weight of significance in the comparative study of geographic ideas and knowledge.

Scholarly journal articles and books written by professional geographers are the main records of academic geographic ideas and knowledge. Unlike academic geographic ideas and knowledge, indigenous folk geographical ideas and knowledge are not adequately reflected in such professional articles and books, in that their theoretical treatment tends to overlook folk geographic knowledge. They are best reflected in indigenous ethnic group's customs, rituals and folklore 
material, especially in oral narratives such as myths, legends and folktales. Unlike academic (professional) geographic ideas and knowledge, tracing the indigenous "folk" geographical ideas and knowledge held by an ethnic group to a specific time and place is difficult, if not near impossible. The exact date of proverbs and legends that contain indigenous folk geographical ideas and knowledge are usually difficult to find, which accounts for the use of relative dating methods such as "terminus ante quem" (point before which) or "terminus post quem" (point after which) to determine the relative age of oral traditions including myths, legends, folktales and proverbs. However, those oral traditions are especially rewarding sources for documenting indigenous folk geographical ideas and knowledge. For example, the Hakka people's (客家: literally, Guest Households) oral traditions such as their folk songs, legends, and nursery rhymes provide invaluable geographical knowledge in the reconstruction of their origins and the migration routes. The Hakkas are a subgroup of Han Chinese people with North China origins, but they fled to Guangdong and other parts of southern China in a series of migration wave since $2^{\text {nd }}$ century BC.

Robert Redfield argued that great (elite, educated upper class) tradition and little (folk, poorly educated common class) tradition are not independent forces, but are mutually dependent because they affect each other (1958, 71-72). Indeed, many great literary writers and musical composers drew inspiration from the folk traditions of folktales and folk songs. It is widely known that J.W. Goethe's famous Faust owes its plot to a medieval folktale. At the same time, much of Goethe's prose became the source for German proverbs still in use. Such an interaction between traditions is also evident in the comparative study of folk and elite geographic ideas and knowledge. Indigenous folk geographical knowledge and academic geographic ideas and knowledge may be understood as existing side by side and influencing each other in myriad ways.

\subsection{The Study of Folk Knowledge in Geographic Tradition}

The geographic ideas and knowledge held by "professional” (academic) geographers is often place-culture specific, and is associated with a particular national tradition of a particular time. For instance, in the study of ideas relating to humanity-environment relationships, the well known French geographic tradition of "possibilism" in the 1920 s is different from the Chinese tradition of "war against nature" during the time of Mao Zedong in the 1960s (Murphy, 1967: pp. 320-326; Shapiro, 2001). In this sense the book, Geography and National Identity, edited by David Hooson (1994) is an excellent example demonstrating diverse illustrations of different national characteristics of geographic ideas and knowledge. The national identity of geographic ideas and knowledge in different cultures was more distinct during the pre-industrial and pre-modern times than now. As the world has gradually "globalised," with easy dissemination of information and exchange of correspondence, the identity of nations has been weakened with the dominant influence from Anglo-American-based geographers. 
While many different types of geographic ideas and knowledge exist-whether they are "folk" or "academic (professional)" in a "Western" or "non-Western" culture-most current studies of geographic ideas and knowledge in the Englishspeaking world examine the Western academic tradition held by "academic" geographers, and their studies emphasise the academic traditions of North America and Western Europe. Clarence J Glacken's (1967) monumental work, Traces on the Rhodian Shore, is an excellent example of this trend. Surveying vast Western intellectual heritages and covering much wider fields than geographical literature, Glacken, with an exceptional depth of scholarship in his book, narrated the Western history of ideas relating to culture-nature relationships from ancient times to the end of the eighteenth century. His work deals mainly with the intellectual (scholarly) traditions of the West. Scholars would agree with David Hooson, who commented that Glacken's book “stands on its own as one of the most scholarly books written by a geographer, or by a historian of ideas in this century" (Hooson, 1991: p. 155).

A brief overview of other major research works into the history of geographic ideas and knowledge is necessary to see how such influential geographers place indigenous folk geographical knowledge in their study and how they treat folk and academic dichotomy issues. Most works are mainly the documentation and explanation of geographic ideas and knowledge in the academic tradition, and as a result, give little or no attention to indigenous folk geographical knowledge. A well-known geographic thought textbook, Preston James's (1972) All Possible Worlds: A History of Geographical Ideas focuses on the geographic ideas and knowledge held by key geographers of different epochs. James's work covers mainly the scholarly traditions of individual scholars and academic institutions and is consequently a Western European and Anglo-American centred work, although he briefly comments on geographic ideas and knowledge in other parts of the world including Russia, China and Japan. Richard Hartshorne's (1961) The Nature of Geography: a critical survey of current thought in the light of the past is a highly acclaimed classical work on the history and philosophy of geographic ideas and knowledge expounding the author's view on what geography has been and what it should be. Hartshorne's book is an excellent example of a scholarly and academic lineage and investigation into the intellectual discourses on the nature and philosophy of geography in the West. David Livingstone's (1992) highly praised work, The Geographical Tradition, is a different kind of work from the previous works on the history of geographic ideas and knowledge discussed above. Livingstone investigates and expounds on the social context of particular tradition of geographic thought and attempts to refute the practice of "presentism" in writing the history of geography. Ultimately, Livingstone's (1992) book is not as comprehensive as Glacken's work, but is accordingly selective of the social, political, religious and economic contexts of the origins and uses of particular geographic ideas since the Renaissance. Livingstone's work also restricts its scope to the scholarly traditions in the Western world. 
One noteworthy exception to this limited research tradition dealing mainly with academic geographic ideas and knowledge was an enlightened scholar of geographic knowledge, John K. Wright, who argued for the importance and significance of the study of geographic ideas and knowledge held by non-geographers. Wright advocated the study of "the geographical ideas, both true and false, of all manner of people, not only geographers, but farmers and fishermen, business executives and poets, novelists and painters, Bedouins and Hottentots," namely the whole of people's "habit of thinking in geographical terms" (Wright, 1947: p. 12). The geographical terms in Wright's statement can be interpreted as people's own understanding of geographical space, location and place, as well as peopleenvironment relationships. Although the history of geographic ideas and knowledge held by Western academics may be the most important tradition in our discipline at the moment, ignoring the "folk" traditions of the West and the non-Western world may result not only in inhibiting the possibilities of understanding the geographic heritage of the world as a whole, but also denying the opportunity of understanding and ameliorating present day geographic ideas and knowledge from a wider perspective. Such a narrow concentration or constricted mode of studying only Western academic geographic ideas and knowledge may result in the loss of "unrecognised" valuable geographic ideas of the world further afield, as well as the opportunity to improve modern geographic ideas and knowledge by benefiting from knowing and understanding such traditions.

John K. Wright's "geosophy," which is understood as the study of "geographical knowledge of one kind or another" or "the geographical ideas, both true and false, of all manners of people", is a powerful intellectual call for the study of the geographic ideas and knowledge held by non-geographers belonging to folk traditions (Wright, 1947: pp. 13-14). Wright did not formally classify geographical knowledge into the two traditions of folk and elite (academic), but he certainly sought to recognise non-professional geographers' geographical knowledge as a specific and distinguishable type of geographic ideas and knowledge and to include it in the history of geographic thought. Wright (1947: p. 13) wrote:

The historical approach to geosophy implies the study of the history of geographical knowledge, or what we customarily call "the history of geography." This subject is usually understood to deal with the record of geographical knowledge as acquired through exploration and field work, and as formalized and made into a discipline, and most of the work that has actually been done in the field has been restricted to the core area of geographical knowledge to the exclusion of its peripheral zone. There is, however, merit in conceiving it more comprehensively. I have already suggested that geographical knowledge of one kind or another is universal among men, and in no sense a monopoly of geographers.

In the above quotation Wright (1947) implied the existence of the two types of geographic knowledge [thought]. That is, one held by professional geographers 
(core area: great tradition) and one held by non-geographers (peripheral zone: little tradition). Wright advocated the study and integration of indigenous folk geographical knowledge with academic geographical knowledge in the history of geography.

\subsection{The Need for Cross-Cultural Studies of Geographic Ideas and Knowledge}

One of the most common forms of studying geographic ideas and knowledge in English speaking nations, such as Great Britain and the USA, is the documentation and interpretation of geographic ideas and knowledge on a temporal scale (a chronological order) from ancient to modern times. This type of study was mainly concerned with a Western nation or Western civilisation as whole. Of course, the Western geographic ideas and knowledge of the past needs to be studied, but we should not forget to monitor and document contemporary as well as traditional geographic ideas and knowledge in the non-Western civilisations.

A particular geographic idea is perhaps formed through intricate interrelationships with other referential ideas and social conditions of the time and place. Therefore it is important to consider geographic ideas in a much more expansive cultural context through time and place. Suitable reasons for the study of geographic ideas and knowledge in a cross-cultural context are summarised as follows:

1) By comparing and contrasting one culture's geographic ideas and knowledge with another cultural tradition, a culture's geographic ideas and knowledge can be understood and delineated more clearly. This case for the integrated study of folk and elite traditions is analogous to the fact that an important benefit of learning a foreign language is, not just the acquisition of another language, but learning one's own native tongue better through the opportunity of comparing and contrasting it with the foreign language that one learns. In a similar way, by elucidating some similarities and differences between geographic ideas from different cultures, one can understand the geographic ideas and knowledge from one's own culture better. For instance, one's own understanding of the French national geographic traditions such as with Vidal de la Blache and his "possibilism" can benefit from comparing and contrasting it with the German and English traditions. It is only after having a comprehensive survey that one is able to talk about the originality and the importance (the true worth) of certain geographic ideas specific to time and place.

2) Having knowledge of geographic ideas and knowledge from other cultures can provide an opportunity for ameliorating one's own geographic ideas and knowledge by bringing into play fresh ideas and perspectives. This fact is plain and not even necessary to explain at length but one can draw the reader's attention to the impact of German geographic ideas and knowledge, such as Ratzel's environmental determinism and Christaller's central place theory, upon the geographic traditions of English speaking nations. The introduction of Western geographic approaches and modes of thought have revolutionised East Asian (Chinese, Japanese and Korean) geographic traditions. 
3) Because all cultures and national histories are interrelated to various degrees, it is possible that geographic ideas and knowledge belonging to a particular nation or culture may have originated from, or at least have originally referenced other cultures. In a true sense, completely indigenous, independent and original geographic ideas and knowledge may well be extremely rare or may not exist at all. If these traditions of geographic ideas and knowledges are independent, the degree of their independence needs to be examined. Tracing the genealogy of geographic ideas in a cross-cultural context is an essential research task for scholars of geographic ideas and knowledge.

The origin and development of some traditions of geographic ideas and knowledge are obvious and one can document with little exertion their relationships with and references to other (or earlier) geographic ideas and knowledge. For instance, Stop-and-Go Determinism proposed by Griffith Taylor is obviously based on and developed from Environmental Determinism promoted by F. Ratzel (1921-1922), S. Semple (1911) and E. Huntington (1924). Even French posibilism sprung out as a reaction to the prominent Environmental Determinism of the time.

However, it is worth pointing out that sometimes the relationship between some well known and popular geographic ideas and knowledge in different parts of the world are unclear or are difficult to prove the provenance of, even if they show some place or temporal based similarities. For instance, the well known Yin-Yang theory from China and The Canticle of Brother Sun by St. Francis of Assisi both dichotomised the natural environment into two contrasting categories: Yin-Yang or Brother-Sister. In Chinese Yin-Yang theory, Yang is male, father, brother, projected, bright, sky, etc., while Yin is female, mother, sister, hollowed, dark, earth, etc. East Asians would divide all natural and human phenomena into either Yang or Yin categories. In The Canticle of Brother Sun St Francis (1182-1226) categorised the Sun, wind, fire as "Brother", while the Moon and the stars, water, Mother Earth as "Sister" (St. Francis, 1958: p. 317). The characterisation of "Brother" and "Sister" in The Canticle corresponds to the Yang and Yin in the Chinese theory, for Brother Sun and Brother fire have Yang characteristics in the Chinese counterpart, while Sister Moon, Sister Mother Earth and Sister water belong to the Yin category. The famous medieval saint, Francis of Assisi emphasised communion with nature and personified non-human life as brother or sister in a somewhat congruent manner to Yin and Yang. Are these two separate bifurcation systems of dichotomising natural phenomena somehow related? Or are the corresponding classifications purely accidental and entirely unrelated? These questions may never be answered (or never be answerable), but pose a challenging topic for a serious geographic ideas and knowledge researcher.

These three reasons above illustrate the current need to study geographic ideas and knowledge in a cross-cultural context instead of simply singling out one particular national or cultural privileging over another. 


\section{The Importance of Indigenous Folk Geographical Ideas and Knowledge - A Case of an Oral Tradition of the Maori in New Zealand}

In this paper, indigenous folk geographical knowledge refers to any geographic information or ideas based by an ethnic group on their oral tradition or folklore. John K. Wright argued that "the habit of thinking in geographical terms is widespread among many peoples" and "the Eskimos, some of the Bedouins, some of the Polynesians, have truly marvellous topographical powers" (1966). Indeed, the indigenous people of New Zealand, Maori, have a rich oral tradition reflecting their geographic ideas and knowledge, or borrowing Wright's (1966) expression, "the habit of thinking in geographical terms". Reflecting well of their attitudes toward the natural environment, the Maori creation myth suggested that the environmental elements and humanity are in a family relationship in human terms. According to the myth, the whole world originated from Rangi (sky-father) and Papa (earth-mother) who gave birth to all branches of environmental families such as the forest, the sea and fish, cultivated food, wild food, the wind and storms as well as humanity (Grey, 1974: pp. 1-11) (See, Figure 1).

In the myth, people ( $\mathrm{Tu}$-matauenga) are one of the six principal children of sky-father and earth-mother and a brother of other environmental families such as forest and sea. When all the children, except Tawhiri-matea (wind and storms), plotted to and succeeded in the separation of Rangi and Papa from their perpetual embrace, the wind of storms paid devastating revenge on the other children (siblings), representing such elements as earth, forest, sea and fish. Tu-matauenga who successfully resisted the fierce attack by the wind then, took revenge on people's earthly siblings such as forest, birds, and fish by eating them as food.

There is evidence that this myth was accepted among traditional Maori society as true history in much the same way as the creation myth in Genesis is accepted as truth by Christians who interpret the bible literally (Yoon, 1986: p. 31; Yoon, 1994: pp. 297-298). Geographical ideas and knowledge as reflected in the Maori myth were the basis of the Maori geomentality ${ }^{1}$ and were held by Maori people in traditional society in their interaction with nature (Yoon, 1986: p. 31). The

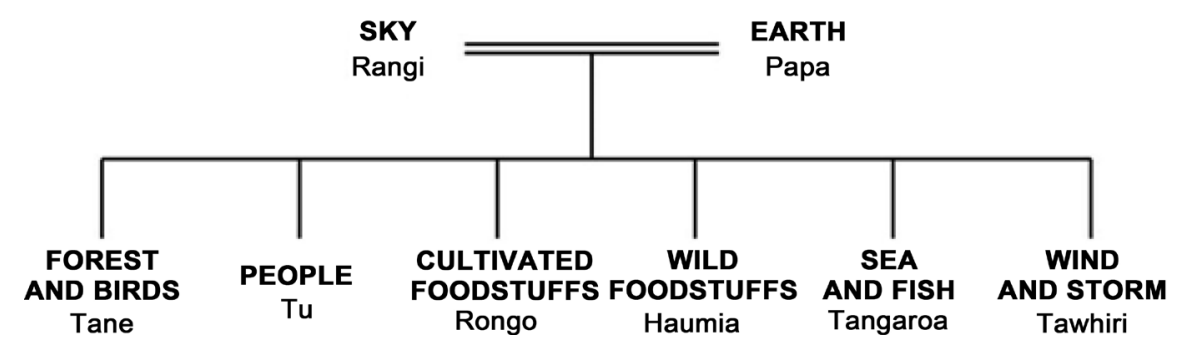

Figure 1. The Maori concept of the environment as family: the family composition of Rangi (Sky) and Papa (Earth) (From Yoon, 1986: p. 32).

${ }^{1}$ The term, geomentality is defined as "an established manner or taken-for-granted way of cognising the environment which conditions humanity-nature relationships; namely, human mentality regarding geographical environment which is held by a group of people or an individual” (Yoon, 1986: p. 39). 
main points of "indigenous folk geographical ideas and knowledge (Maori geomentality)" as reflected in the Maori creation myth can be summarised as follows (Yoon, 1994: pp. 300-306):

1) The environment is personified and recognised as having a family structure similar to a human family. The Sky and the Earth are as a married couple and their children include the forest and birds, people, ocean and fish, etc.

2) Humanity is an integral member of nature either as a brother to the forest, birds, sea, and fish or as one of the children to the parents, the Sky and the Earth. However, people were considered as a conqueror of natural resources including the forest and the sea on the earth. Thus, people, as a conqueror, had the right to use the earth's resources, and as a result, the collection of their foodstuff was justified.

3) Although their consumption of natural resources was justified, their use necessitates a certain harmony with nature. This idea is more clearly reflected in the Maori mythical legend of "Adventures of Rata, the enchanted tree" (Grey, 1974: pp. 84-88). In the story, Rata, a warrior, could not make a canoe out of a suitably good quality tree due to nature's mysterious interference until he goes through proper rituals (prayers) before cutting the tree. The myth suggests that only when humans maintain appropriate harmonious relationships with nature, can they have beneficial relationships with nature.

Maori proverbs also support the Maori people's traditional geographic knowledge and their attitudes toward nature as outlined above (Yoon, 1979: pp. 636637; Firth, [1959] 1973, Chapter XI The Land, pp. 367-392). Some examples of such proverbs and basic Maori attitudes toward nature include "Earth is humanity's parents" (Kohere, 1951: p. 16) and "Food supplies the blood of people, Land supplies food for people" (Kohere, 1951: p. 16; Brougham and Reed, 1963: p. 63). Maori proverbs, such as "A man will fight to the death for his land and his women" manifest their intense sentiment (attachment) toward their home territory (turangawaewae) (Best, 1941: p. 297; Kawharu, 1977: p. 34). These proverbs effectively connote the unique Maori sense of place that relates to their home territory.

The traditional Maori geographic knowledge and attitudes toward nature form important governing principles of people's relationships with their "environmental" siblings or other offspring of the mother earth. This Maori tradition is an example of "the habit of thinking in geographical terms", and is incorporated in the New Zealand Resource Management Act (RMA henceforth) (New Zealand Government, 1991). One of the RMA's specifically defined purposes is to promote the sustainable management of natural resources, and the RMA lists "kaitiakitanga", the traditional Maori wisdom of environmental management as one of the guiding principles to achieve this purpose (Section 5 [1] \& Section 7). Kaitiakitanga is the traditional Maori "act of guardianship", regulating the relationships among the various offspring (environmental elements) of Papatuanu$\mathrm{ku}$ (earth Mother) in the traditional Maori society by complex tribal customary practices and laws that include the institution of rahui or the prohibition of re- 
source exploitation from an imposed area for an imposed time period (Roberts et al., 1995: p. 12; Marsden, 1998: pp. 25-26). It defines and summarises the Maori perspectives on conservation and environmental ethics that is holistic and ensures harmony within the environment (Roberts et al., 1995: pp. 7, 12; Minhinnick, 1989: p. 5).

Here we can see that New Zealand's RMA (official tradition or "great tradition" using Redfield's term) benefits from traditional Maori knowledge of oral tradition regarding environmental management which is "folk tradition" in his classification. On the other hand, New Zealand law (RMA), the official tradition, regulates and governs the general public (folk tradition) of the New Zealand society in resource management affairs. As shown in New Zealand's traditional Maori culture and modern RMA, "folk" tradition and the official or great tradition interact and influence each other. The occurrence of the two types of geographic ideas and knowledge can be seen not only in New Zealand, but also in other nations of non-Western cultures, such as the Korean culture. Korean geomancy tales (Yoon, 1975; Yoon, 1980b), for instance, reflect traditional Korean folk geographic knowledge and their attitudes toward nature. The analysis of geomantic folk narratives reveals that Koreans used to conceive nature as a magical being that could bless or hurt people; as a personified being that is treated as an animate or inanimate object such as a cow or a sailing boat; and as a vulnerable being that could be destroyed or remedied by humans (Yoon, 1980a; Yoon, 2003). The folk narratives such as legends, folktales and myths are effective sources for exposing traditional Korean geomantic attitudes toward nature, important indigenous folk geographical ideas and knowledge of Korea.

Examining folk narratives specific to the time and place of a culture and its traditions provides ingenious insights into the distinctive geographic ideas and knowledge held by different ethno-cultural groups. These oral traditions, which have been around since before literacy, have the tendency to be believed as real and contain as much historical fact as the stories in Genesis. The creation myths in Genesis have been the source for important aspects of Western attitudes toward nature.

In the study of geographic ideas and knowledge, we have two important works representing each of the two traditions. Clarence J. Glacken's (1967), Traces on the Rhodian Shore is a monumental example of documenting geographic ideas and knowledge in the great (academic) tradition, while J.K. Wright's (1965) The Geographical Lore of the Time of the Crusades may well also be that of the folk (commoners) tradition. We need to study both traditions, because both are interdependent and integral parts of the study of geographic ideas and knowledge.

\section{Contributions of Folk Geographical Knowledge?}

Geographers have previously given insufficient attention to the study of indigenous folk geographical ideas and knowledge. However, some compelling reasons exist in dichotomising geographic ideas and knowledge into the two defining 
categories of "academic" and "folk," and bringing into scholars' attention folk tradition as a valuable source of geographic ideas and knowledge. The following three point discussion highlights how indigenous folk geographical ideas and knowledge adds another dimension to the understanding of geographic ideas and knowledge in an elite (professional) or academic setting:

1) Indigenous folk geographical ideas and knowledge exist and interact with the academic (professional) tradition by providing multiple insights into geographic phenomena, such as spatial patterns and human-environment relationships. For instance, folk and academic geographic ideas and knowledge exist simultaneously in the cultural environment of contemporary East Asia. In the arena of the academic geographic tradition, contemporary Korean and Chinese geographers classify landforms into plateaus, basins, pediments, alluvial fans, etc. using contemporary geomorphologic terms. On the other hand, folk geomancers in China and Korea, who divine land to find auspicious sites, still classify mountains into five types according to Yin-Yang and the Five Elements Theory-fire, water, earth, wood and metal-depending on their shape (See, Figure 2).

Even within one culture, great tradition and folk tradition co-exist. It is interesting to know the nature of and interaction between the two parallel geographic ideas and knowledge. The Korean folk tradition of geomancy, which classified mountains into five types, was one of a series of criteria considered in the process of the recent site selection and city planning of the second Korean capital for the central government administration. This contested case demonstrates the interesting interaction of indigenous folk geographical ideas and knowledge with and contribution to the professional geographical circle.

2) Geographers study the interactions of people, places and landscapes. The people that geographers deal with are generally non-geographers and non-academics who belong to various folk groups. It is important to note here that the geographic

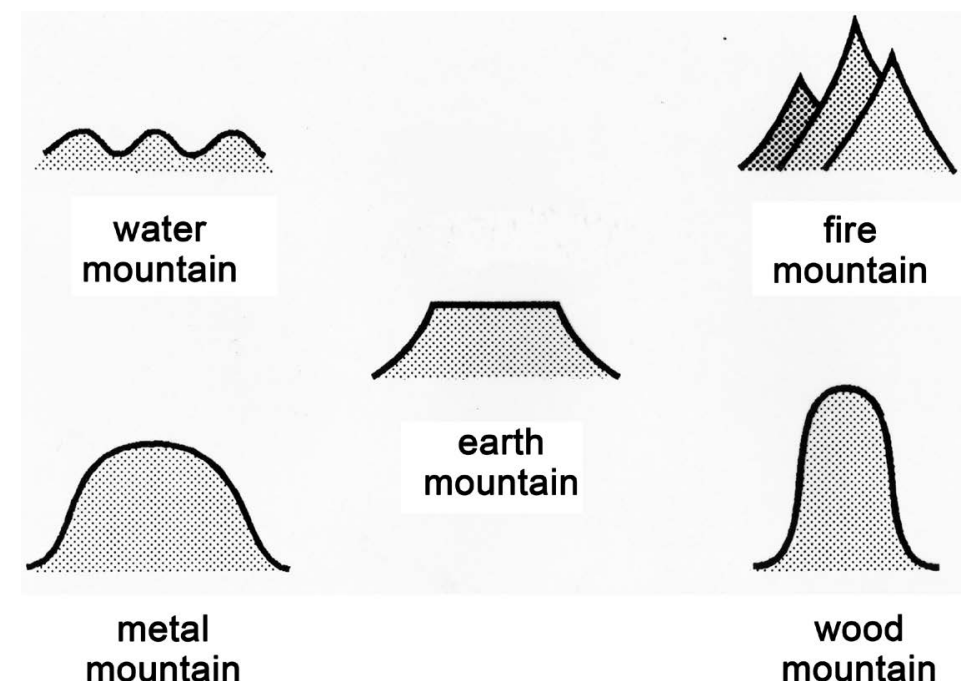

Figure 2. A folk classification of mountain types into five categories according to the Yin-Yang and the Five Element Theories in geomancy (fengshui in Chinese; p'ungsu in Korean) (From Yoon, 2006, 82). 
ideas and knowledge held by any folk group can enlighten academics (professional geographers) with their deep insights into place (locality), landscape and life, as a result of their everyday living experiences. Folk groups generate rich folk traditions that encompass oral folklore such as legends and proverbs. It is in this way that an indigenous people's proverbial sayings can reveal a people's indigenous folk geographical ideas and knowledge in an ingenious way, for they encapsulate "a distilled expression of people's wisdom, ideas and values" (Yoon, 1986: p. 18). For example, the intense Maori (the people of New Zealand) sentiment for their ancestral land and the bond with their home land is well expressed in their proverbial sayings, such as, "Mine is the land, the land of my ancestors", "I greet my only surviving parent in the world, the land" or "For woman and land men are lost" (Firth, 368). For an academic geographer who studies the unique sense of Maori places, what is invaluable is the geographic ideas and knowledge that is the deep feeling for and attachment to the ancestral land veiled in these proverbs. An appreciation of these proverbial sayings will provide clues to the Maori sense of place and way of life centred on their land. In this way, various genres of folk traditions including proverbs and folk narratives are important sources for indigenous "folk" geographical ideas and knowledge. Tapping into this folk knowledge can provide original and invaluable insights for academics in their geographic research and field work ventures.

Maxims reflecting the cultural ecology of local environments exist among different cultures. For instance, in water-deficient North China, as a way of discouraging children from using excessive amounts of water, parents might say to their children: "do not use water too much, for you will be asked to drink up all the excess water you have used when you are at the final judgement after death." (personal communication with the Late Professor Wolfram Eberhard, UC Berkeley Campus, 1972). As a result, every attempt was made to conserve water in the dry belt of north China. In Korea, the months of May and June in the lunar calendar are the busiest for peasants in their annual agricultural cycle. The old saying went that in May and June of rice transplanting season, peasants would like to hire even the paws of a cat for farm work (a well known proverb in a Korean village where I grew up). This peasant proverbial saying reveals cultural ecological conditions of traditional rice farmers in Korea and how desperate they were in seeking assistance from every available farm hand. The folk wisdom embedded in the above proverbs is in fact exemplary indigenous folk geographical knowledge that can shed initial insights into the land and people that an academic geographer might study. These proverbs can provide an ingenious key to unlocking the principles and characteristics particular of any place, people and landscape which academic geographers study. It is in light of this knowledge that academic geographers are urged to give more attention to the geographic ideas and knowledge embedded in various forms of folk tradition such as proverbs and folk narratives.

3) The study of indigenous folk geographical knowledge will open up new 
fields of study that academic geographers rarely studied or considered in the past. Tapping into folk ideas, including their wishes and understanding of the world as reflected in the oral tradition, can provide invaluable insights into a study of any folk group, such as peasant communities in rural Vietnam or ethnic ghettos of North American cities. In the study of indigenous "folk" geographical ideas and knowledge, academic geographers may find it useful to give attention to the so called emic/etic distinction (insider/outsider understandings). Marvin Harris eloquently clarified that the emic/etic distinction popular among ethnologists in the 1960s and 1970s corresponds more or less to "how people actually behave in the judgement of anthropological observers versus how people think of themselves as behaving, their purpose for behaving in such a manner, and their own explanation of their behaviour" (Harris, 1971: pp. 146-149).

If one is to apply the emic/etic distinction to the study of folk geographic tradition an etic (outside perspective) approach is understood as an academic geographer's discussion of indigenous folk geographical ideas and knowledge as observed, surveyed and objectively judged by the observer, while an emic (inside perspective) study is a report narrating how people themselves explain their geographic behaviour and on what ground they explain so. An academic geographer's study of indigenous folk geographical knowledge requires both etic and emic knowledge. One can effectively achieve emic research of indigenous folk geographical ideas and knowledge by tapping into the ideas as engraved in a folk group's valued oral traditions such as legends and proverbs. For example, weather folklore and sayings can reveal a local group's insightful understanding of their village's weather conditions as related to their livelihood, while a joke about a suburban neighbourhood can insightfully point out place identity, social network or other cultural geographic phenomena of the place.

\section{Conclusion: The Value of Studying Folk Geogrpahical Ideas and Knowledge}

Although present day geographers seldom meaningfully heed John K. Wright's call for the study of "geosophy", for a better understanding of geographic heritages of the world, cross-cultural studies of folk geographic ideas and knowledge are indispensable. In order to achieve this goal of a more enlightened study of geographic ideas and knowledge, this paper advocates that researchers of geographic thought need to give more attention to the geographical ideas and knowledge held by various indigenous (native) people of the world, who can provide emic (inside) knowledge of their culture-environment relationships and explain them more comprehensively. Scholars of geographic thought also need to tap into folk geographic knowledge from various socio-economic groups within an ethnic culture such as disadvantaged urban ghettos, isolated rural peasant villages, and abandoned mining towns. My discussion on indigenous folk geographic ideas and knowledge held by New Zealand Maori demonstrates the need for comparative studies of geographic ideas and knowledge held by 
various folk and elite traditions within a nation or a culture. Unlike studies of academic geographical ideas that document the biographies of professional geographers, the study of folk geographic ideas and knowledge requires us to focus on the biographies of different geographic ideas and knowledge in the folk tradition. A much broader and inclusive approach is called for the study of geographic ideas and knowledge.

\section{Acknowledgements}

I am grateful to Associate Professor Caroline Sokyong Yoon of The University of Auckland for her critical reading of this manuscript and editorial help.

\section{References}

Best, E. (1941). The Maori (2 Vols). Wellington: Polynesian Society.

Blaut, J. M. (1979). Some Principles of Ethnogeogrphy. In S. Gale, \& G. Olsson (Eds.), Philosophy in Geography (pp. 1-7). Dordrecht, Holland: D. Reidel Publishsing Company. https://doi.org/10.1007/978-94-009-9394-5_1

Brougham, A., \& Reed, A. (1963). Maori Proverbs. Wellington: A.H. and A.W. Reed.

Dundes, A. (1965). The Study of Folklore. Englewood Cliffs, N.J.: Prentice-Hall.

Dundes, A. (1972). Anthropology 159, The Study of Folklore. Fybate Lecture Notes, Berkeley, California (Lecture Notes on a Course at U.C. Berkeley).

Firth, R. (1959). Economics of the New Zealand Maori. Wellington NZ: A. R. Shearer, Government Printer.

Glacken, C. J. (1967). Traces on the Rhodian Shore. Berkeley: University of California Press.

Grey, S. G. (1974). Polynesian Mythology and Ancient Traditional History of the New Zealanders. Christchurch: Whitcombe \& Tombs.

Harris, M. (1971). Culture, Man, and Nature: An Introduction to General Anthropology. New York: Thomas Y. Crowell Company.

Hartshorne, R. (1961). The Nature of Geography: A Critical Survey of Current Thought in the Light of the Past. Lancaster, Penn: Association of American Geographers.

Hooson, D. (1991). Clarence Glacken 1909-1989. Annals of the Association of American Geographers, 81, 152-158. https://doi.org/10.1111/j.1467-8306.1991.tb01684.x

Hooson, D. (1994). Geography and National Identity. Oxford: Blackwell.

Huntington, E. (1924). Civilization and Climate (3rd ed.). New Haven: Yale University Press; London: Humphrey Milford, Oxford University Press.

James, P. E. (1972). All Possible Worlds. A History of Geographical Ideas. A History of Geographical Ideas. Indianapolis: The Odyssey Press.

Kawharu, I. H. (1977). Maori Land Tenure: Studies of a Changing Institution. Oxford: Oxford University Press.

Kohere, R. (1951). He Konae Aronui, Maori Proverbs and Sayings. Wellington, NZ: A.H. and A.W. Reed.

Livingstone, D. (1992). The Geographical Tradition. Oxford: Blackwell.

Marsden, M. (1988). The Natural World and Natural Resources: Maori Value Systems and Perspectives. Resource Management Law Reform Working Paper No. 29, Part A, Wellington: Ministry for the Environment. 
Minhinnick, N. K. (1989). Kaitiaki. Auckland: Print Centre.

Murphey, R. (1967). Man and Nature in China. Modern Asian Studies, 1, 313-333. https://doi.org/10.1017/S0026749X00002638

New Zealand Government (1991). Resource Management Act 1991: An Act to Restate and Reform the Law Relating to the Use of Land, Air and Water. Wellington, NZ: Published under the Authority of the New Zealand Government.

Ratzel, F. (1921-1922). Anthropogeographie. Stuttgart: J. Engelhorns Nachf.

Redfield, R. (1958). Peasant Society and Culture: An Anthropological Approach to Civilization. Chicago: The University of Chicago Press.

Roberts, M., Waerete, N., Nganeko, M., Del, W., \& Carmen, K. (1995). Kaitiakitanga: Maori Perspectives on Conservation. Pacific Conservation Biology, 2, 7-20. https://doi.org/10.1071/PC950007

Semple, E. (1911). Influences of Geographic Environment on the Basis of Ratzel's System of Anthropogeography. New York, NY: Henry Holt and Company; London: Constable \& Company, Ltd.

Shapiro, J. (2001). Mao's War against Nature: Politics and the Environment in Revolutionary China. Cambridge: Cambridge University Press.

https://doi.org/10.1017/CBO9780511512063

St. Francis (1958). The Little Flowers of St. Francis (Trans. by Raphael Brown). New York, NY: Image Books.

Wright, J. K. (1947). “Terrae Incognitae”: The Place of the Imagination in Geography. Annals of Association of American Geographers, 37, 1-15.

https://doi.org/10.1080/00045604709351940

Wright, J. K. (1965). The Geographical Lore of the Time of the Crusades. New York, NY: Dover Publications.

Wright, J. K. (1966). A Pleas for the History of Geographic Thought. In J. K. Wright (Ed.), Human Nature in Geography (pp. 11-23). Cambridge, MA: Harvard University Press.

Yoon, H.-K. (1975). An Analysis of Korean Geomancy Tales. Asian Folklore Studies, 34, 21-34. https://doi.org/10.2307/1177738

Yoon, H.-K. (1979). Folklore and the Study of Environmental Attitudes. Annals of the Association of American Geographers, 69, 635-637. https://doi.org/10.1111/j.1467-8306.1979.tb01287.x

Yoon, H.-K. (1980a). The Image of Nature in Geomancy. GeoJournal, 4, 341-348. https://doi.org/10.1007/BF00219581

Yoon, H.-K. (1980b). The Value of Folklore in the Study of Man's Attitudes toward Environment. New Zealand Environment, 27, 13-15.

Yoon, H.-K. (1986). Maori Mind, Maori Land: Essays on the Cultural Geography of the Maori People from an Outsider's Perspective (p. 138). Berne, Frankfurt, New York, Paris: Peter Lang.

Yoon, H.-K. (1994). Chapter 20, Maori Identity and Maori Geomentality. In D. Hooson (Ed.), Geography and National Identity (pp. 293-310). The Institute of British Geographers Special Publications Series 29, London: Blackwell.

Yoon, H-K. (2003). A Preliminary Attempt to Give a Birdseye View on the Nature of Traditional Eastern (Asian) and Western (European) Environmental Ideas. In E. Ehlers, \& C. F. Gethmann (Eds.), Environment across Cultures (pp. 124-142). Berlin: Springer-Verlag. https://doi.org/10.1007/978-3-662-07058-1_9 